\title{
Protective effect of melatonin against zonisamide-induced reproductive disorders in male rats
}

\author{
Wagdy K.B. Khalil' ${ }^{1}$, Faiza Abdu²
}

${ }^{1}$ Cell Biology Department, National Research Centre, Dokki, Giza, Egypt

2Department of Biological Science, Faculty of Science, King Abdulaziz University, Jeddah, Saudi Arabia

Submitted: 13 April 2013

Accepted: 18 June 2013

Arch Med Sci 2015; 11, 3: 660-669

DOI: $10.5114 /$ aoms.2013.39384

Copyright @ 2015 Termedia \& Banach

\section{Abstract}

Introduction: Zonisamide (ZNS) is a modern antiepileptic drug (AED) that is distinguished from other AEDs by its unique structure and broad mechanistic profile. The pineal hormone melatonin is involved in the regulation of reproductive function, including the timing of the luteinizing hormone (LH) surge. The aim of the present work was to study the protective effect of melatonin against the potential suppression impact of ZNS on reproductive activity.

Material and methods: Ninety adult albino male rats were allocated to several groups treated with melatonin (10 mg/kg BW), ZNS (10, 20 and $50 \mathrm{mg} / \mathrm{kg} \mathrm{BW}$ ) and $10 \mathrm{mg} / \mathrm{kg}$ of melatonin plus ZNS (10, 20 or $50 \mathrm{mg} / \mathrm{kg} B W$, respectively). Reproductive hormones (testosterone, LH and follicle-stimulating hormone (FSH)) levels were measured in animal serum. Sperm abnormalities and DNA fragmentation in testis tissues as well as expression alteration of several reproductive-related genes were analyzed.

Results: The results revealed that ZNS decreased the levels of serum free testosterone, $\mathrm{LH}$, and FSH and expression of their encoding genes in male rats. In addition, ZNS treatment increased the sperm abnormalities and DNA fragmentation and inducible nitric oxide synthase (iNOS) in testis tissues as well as GABA level in liver tissues. However, melatonin supplementation inhibited the negative symptoms of ZNS in which it increased the levels of reproductive hormones and expression of their encoding genes in the ZNS-treated rats. Moreover, melatonin decreased the sperm abnormalities, DNA fragmentation, iNOS activity and GABA level in ZNS-treated rats.

Conclusions: The data obtained in this study suggest that melatonin administration confers protection against toxicity inflicted by ZNS, and support the contention that melatonin protection is achieved by its ability as a scavenger for free radicals generated by ZNS.

Key words: zonisamide, melatonin, testosterone, luteinizing hormone, follicle-stimulating hormone, gene expression, DNA damage.

\section{Introduction}

Zonisamide (ZNS) (Zonegran ${ }^{\circledR}$; Eisai Inc, Teaneck, NJ, USA) is a newer, broad-spectrum antiepileptic drug (AED) that has been shown to be effective in the treatment of refractory partial seizures [1, 2]. Chemically classified as a sulfonamide, ZNS is characterized by a unique structural, mechanistic, and pharmacokinetic profile that is distinct from that of other AEDs. Zonisamide is a benzisoxazole derivative, originally synthesized in Japan in 1974 during exploratory research on psychiatric drugs, where it

\author{
Corresponding author: \\ Dr. Wagdy K. B. Khalil \\ Cell Biology Department \\ Genetic Engineering \\ and Biotechnology Division \\ National Research Centre (NRC) \\ 33 El-Bohouth Street \\ 12622 Dokki, Giza, Egypt \\ Phone: +20122-7410600 \\ Fax: +202-33370931 \\ E-mail: \\ wkbassaly@gmail.com, \\ wagdykh@yahoo.com
}


was subsequently identified as having anticonvulsant activity during screening [3]. Preclinical animal studies conducted in Japan revealed the anti-seizure effects of zonisamide on maximal electroshockinduced seizures in rats, mice, rabbits, and dogs.

It is also effective for the management of migraine [4], neuropathic pain [5], essential tremor [6], anxiety [7], and other conditions. Recently, ZNS has been approved as a new adjunctive therapy for motor complications of Parkinson's disease (PD) in Japan [8]. More recently, ZNS was reported to be effective for the management of impulse control behavior in PD [9], suggesting potential effects on non-motor PD symptoms.

Melatonin, N-acetyl-5-methoxytryptamine, is a hormone secreted mainly by the pineal gland. Retinal light exposure reduces the amount of serotonin metabolized to melatonin via neural pathways connecting the retina to the pineal gland. Thus, pineal production of melatonin increases at night, and the amount of melatonin secreted into the plasma is related to the length of exposure to darkness [10]. Melatonin is involved in the modulation of a variety of endocrine, neural, and immune functions [10, 11]. Gonadotropin-releasing hormone $(\mathrm{GnRH})$ neurons represent the final output neurons in the central control of the reproductive system. Gamma-amino butyric acid (GABA), one of the major regulators of GnRH neurons, depolarizes GnRH neurons isolated from adult rats via GABA $(A)$ receptors. The presence of GABA (A) receptors in $\mathrm{GnRH}$ neurons has also been demonstrated morphologically [12]. The pineal hormone melatonin is involved in the regulation of reproductive function, including the timing of the luteinizing hormone surge. The suprachiasmatic nucleus and the GABAergic system in the medical pre-optic area are considered as possible sites of the action of melatonin [12].

The effect of melatonin on the hypothalamus pituitary axis and therefore the reproductive system have initiated studies aimed at the use of melatonin as an oral contraceptive [13]. When using high doses of melatonin (75 and $300 \mathrm{mg}$ daily) in combination with norethisterone, no peak in luteinizing hormone (LH) secretion was observed during the menstrual cycle. Furthermore, plasma follicle-stimulating hormone (FSH) levels remained constant. These circumstances prevented ovulation and the increase in progesterone during the luteal phase. The suggested mechanism of action involved antigonadotropic effects on the hypothalamus, such as alteration in the hypothalamic pulsatile GnRH secretion and/or effects on the pituitary release of $\mathrm{LH}$, or even a direct effect on the ovary. Due to melatonin's side effects (especially sleep induction, etc.) this possibility now is viewed rather skeptically [14].

Melatonin exhibits some protective functions for cells against noxious agents, acts as a powerful antioxidant and scavenger of free radicals, and counteracts the generation of free radicals by inhibiting the activity of inducible nitric oxide synthase (iNOS) [15]. Melatonin shows a similar activity in purification of peroxide radicals $\left(\mathrm{ROO}^{-}\right)$, a consequence of lipid peroxidation, thus being a more powerful antioxidant than vitamin $\mathrm{E}[16,17]$. Therefore, we hypothesize that melatonin could be highly specific against lipid peroxidation for several reasons: it is highly lipophilic, it is usually found in high concentrations in cell membranes and, like vitamin $\mathrm{C}$ and $\mathrm{E}$, it reduces the oxidation of lipids due to its purifying activity towards the $\mathrm{OH}^{-}$radical [18]. Although the protective mechanism of melatonin has not been completely clarified, in most cases it is of great interest to investigate whether melatonin could prevent the potential cytotoxic effects of ZNS in male rats. Therefore, several reproductive parameters including alterations in serum levels of free testosterone, $\mathrm{LH}$, and FSH and their encoding gene expression, sperm abnormalities and DNA fragmentation in male rats were examined.

\section{Material and methods}

\section{Experimental animals}

Ninety adult albino male rats (100-120 g), purchased from the Animal House Colony, Giza, Egypt, were maintained on a standard laboratory diet (protein $16.04 \%$, fat $3.63 \%$, fiber $4.1 \%$, and metabolic energy $0.012 \mathrm{MJ}$ ) and water ad libitum at the Animal House Laboratory, National Research Centre, Dokki, Giza, Egypt. After an acclimation period of 1 week, animals were divided into groups (10 rats/ group) and housed individually in filter-top polycarbonate cages, housed in a temperature-controlled $\left(23 \pm 1^{\circ} \mathrm{C}\right)$ and artificially illuminated (12 h dark/light cycle) room free from any source of chemical contamination. All animals received humane care in compliance with the guidelines of the Animal Care and Use Committee of the National Research Centre, Egypt.

\section{Experimental design}

The male rats were randomly allocated to 9 groups ( $n=10$ per group) and treated intragastrically for 4 week as follows: group 1, control group: animals were treated with solvent vehicle control $(\mathrm{NaCl})$; group 2, animals were treated with melatonin (10 mg/ kg BW, [19]); groups 3-5, animals were treated with 10,20 and $50 \mathrm{mg} / \mathrm{kg}$ BW of zonisamide (ZNS, [20]), respectively; groups $6-8$, animals were treated with melatonin (10 mg/kg BW) plus ZNS (10, 20 and $50 \mathrm{mg} /$ kg BW, respectively); group 9, animals were injected intraperitoneally (i.p.) with cyclophosphamide (CP) alone (25 mg/kg BW, as a single injection) $24 \mathrm{~h}$ prior to their sacrifice.

All animals were sacrificed by cervical dislocation after $24 \mathrm{~h}$ of CP injection. Half of the animals per 
group ( $n=5)$ were used for hormone analysis, DNA fragmentation and gene expression analyses. The other half of the animals were kept for 35 days after the last dose of treatment for sperm morphology.

\section{Biochemical analyses}

Quantitative estimation of free testosterone was carried out in the sample of rat's serum using enzyme-linked immunosorbent assay (ELISA) according to McCann and Kirkish [21]. Quantitative estimation of FSH was carried out in the sample of rat's serum using ELISA according to Knobil [22]. Quantitative estimation of LH in the sample of rat's serum was carried out using ELISA according to Wakabayashi [23]. The kits used for determination of free testosterone, $\mathrm{FSH}$ and $\mathrm{LH}$ in rat serum were obtained from Gloryscience Co., Ltd.

\section{$\gamma$-Aminobutyric acid measurements}

For determination of the content of GABA liver tissues were used to carry out the analysis. Liver tissues (100 mg) were homogenized on ice with icecold phosphate buffer saline. Afterwards, liver cells were washed twice with developmental buffer (DB: $5 \mathrm{mM} \mathrm{Na}_{2} \mathrm{HPO}_{4}, 5 \mathrm{mM} \mathrm{KH}_{2} \mathrm{PO}_{4}, 0.2 \mathrm{mM} \mathrm{CaCl}_{2}, 2 \mathrm{mM}$ $\mathrm{MgSO}_{4}, \mathrm{pH}$ 6.5), and then suspended in $100 \mu \mathrm{l}$ of DB. The suspension was shaken gently at $120 \mathrm{rpm}$ and $22^{\circ} \mathrm{C}$. After that, the suspension was centrifuged at $1,500 \mathrm{~g}$ for $1 \mathrm{~min}$. A volume of $40 \mu \mathrm{l}$ of supernatant was analyzed for GABA via high-performance liquid chromatography (HPLC). Each measurement was performed at least in triplicate.

\section{Determination of inducible nitric oxide synthase activity}

Inducible nitric oxide synthase (iNOS) activity was determined by an NOS assay kit. The NOS assay kit is to use the method of catalyzing L-arginine to measure NOS activity in testis tissues. Hundred miligrams of testis tissue samples from all the groups of rats were placed in a centrifuge tube, adding 10 volumes of ice-cold phosphate buffer saline (PBS, pH 7.4), and immediately homogenized for 1-2 min on ice; the homogenate was then centrifuged at $3000 \mathrm{r} / \mathrm{min}$ for $15 \mathrm{~min}$ at $4^{\circ} \mathrm{C}$. The supernatant was collected and aliquoted. One of the aliquots was used for detection and the rest were stored at $-80^{\circ} \mathrm{C}$ for future study. Then, the protein concentration was determined by bicinchoninic acid (BCA) Protein Assay Kit. The supernatant was incubated with $0.6 \mathrm{ml}$ of reaction buffer combined with the addition of inhibitor $1 \mathrm{mmol} / \mathrm{I}$ EGTA (ethylene glycol tetraacetic acid, it is iNOS $\mathrm{Ca}^{2+}$ independent and can complex $\mathrm{Ca}^{2+}$ in samples). The reaction was terminated after $15 \mathrm{~min}$ at $37^{\circ} \mathrm{C}$. Photometric measurement of the absorbance at $530 \mathrm{~nm}$ was applied to determine total iNOS activity.

\section{Sperm abnormalities}

Thirty-five days after the last dose (duration of spermatogenesis) [24], half of the animals of each treated group ( 5 animals per group) were sacrificed by neck vertebra luxation. The epididymides and testes from each rat were removed and weighed. Sperm were collected as quickly as possible when each rat was dissected. To release sperm, the cauda epididymides were cut in a pre-warmed Petri dish containing $1 \mathrm{ml}$ of saline solution at $37^{\circ} \mathrm{C}$. After mincing with scalpels, the suspension was stirred and dropped on a grease-free clean slide to determine the motility of sperm using a microscope. Spermatozoa were counted using a hemocytometer and a drop of a homogenate smeared on a cleaned slide allowed to air dry and stained with approximately $0.05 \%$ aqueous eosin $\mathrm{Y}$. The slides were coded and used for the examination of sperm head and tail abnormalities. For each animal 500 sperm were examined for morphological abnormalities according to the criteria of Jeong et al. [25]

\section{DNA fragmentation analysis}

Apoptotic DNA fragmentation was qualitatively analyzed by detecting the laddering pattern of nuclear DNA as described according to Lu et al. [26]. Briefly, liver tissues were homogenized, washed in PBS, and lysed in $0.5 \mathrm{ml}$ of DNA extraction buffer (50 mM Tris- $\mathrm{HCl}, 10 \mathrm{mM}$ EDTA. 0.5\% Triton, and $100 \mu \mathrm{g} / \mathrm{ml}$ proteinase $\mathrm{K}, \mathrm{pH} 8.0$ ) overnight at $37^{\circ} \mathrm{C}$. The lysate was then incubated with $100 \mu \mathrm{g} / \mathrm{ml}$ DNase-free RNase for $2 \mathrm{~h}$ at $37^{\circ} \mathrm{C}$, followed by three extractions of an equal volume of phenol/chloroform $(1: 1 \mathrm{v} / \mathrm{v})$ and a subsequent re-extraction with chloroform by centrifuging at 15,000 rpm for $5 \mathrm{~min}$ at $4^{\circ} \mathrm{C}$. The extracted DNA was precipitated in two volumes of ice-cold $100 \%$ ethanol with $1 / 10$ volume of $3 \mathrm{M}$ sodium acetate, $\mathrm{pH} 5.2$ at $-20^{\circ} \mathrm{C}$ for $1 \mathrm{~h}$, followed by centrifuging at $15,000 \mathrm{rpm}$ for $15 \mathrm{~min}$ at $4^{\circ} \mathrm{C}$. After washing with $70 \%$ ethanol, the DNA pellet was air-dried and dissolved in $10 \mathrm{mM}$ Tris-HCl/ $1 \mathrm{mM}$ EDTA, pH 8.0. The DNA was then electrophoresed on $1.5 \%$ agarose gel and stained with ethidium bromide in Tris/acetate/EDTA (TAE) buffer ( $\mathrm{pH}$ 8.5, 2 mM EDTA, and $40 \mathrm{mM}$ Tris-acetate). A 100-bp DNA ladder (Invitrogen, USA) was included as a molecular size marker and DNA fragments were visualized and photographed by exposing the gels to ultraviolet transillumination.

\section{Expression of aromatase, luteinizing hormone and follicle-stimulating hormone genes}

\section{Isolation of total RNA}

Total RNA was isolated from brain and testis tissues of male rats by the standard TRIzol ${ }^{\circledR}$ Reagent extraction method (cat\#15596-026, Invitrogen, Ger- 
many). Briefly, tissue samples were homogenized in $1 \mathrm{ml}$ of TRIzol ${ }^{\circledR}$ Reagent per $50 \mathrm{mg}$ of the tissue. Afterwards, the homogenized sample was incubated for $15 \mathrm{~min}$ at room temperature. A volume of $0.2 \mathrm{ml}$ of chloroform per $1 \mathrm{ml}$ of TRIzol ${ }^{\circledR}$ Reagent was added. Then the samples were vortexed vigorously for $15 \mathrm{~s}$ and incubated at room temperature for $3 \mathrm{~min}$. The samples were centrifuged at no more than $12,000 x \mathrm{~g}$ for $15 \mathrm{~min}$ at $4^{\circ} \mathrm{C}$. Following centrifugation, the mixture was separated into a lower red, phenol-chloroform phase, an interphase, and a colorless upper aqueous phase. RNA remained exclusively in the aqueous phase. Therefore, the upper aqueous phase was carefully transferred without disturbing the interphase into a fresh tube. The RNA was precipitated from the aqueous phase by mixing with isopropyl alcohol. A volume of $0.5 \mathrm{ml}$ of isopropyl alcohol was added per $1 \mathrm{ml}$ of TRIzol ${ }^{\circledR}$ Reagent used for the initial homogenization. Afterwards, the samples were incubated at $15^{\circ} \mathrm{C}$ to $30^{\circ} \mathrm{C}$ for $10 \mathrm{~min}$ and centrifuged at not more than $12,000 \mathrm{x} g$ for $10 \mathrm{~min}$ at $4^{\circ} \mathrm{C}$. The RNA was precipitated, which was often invisible before centrifugation, forming a gel-like pellet on the side and bottom of the tube. The supernatant was removed completely. The RNA pellet was washed once with $1 \mathrm{ml}$ of $75 \%$ ethanol. The samples were mixed by vortexing and centrifuged at no more than $7,500 \times \mathrm{g}$ for $5 \mathrm{~min}$ at $4^{\circ} \mathrm{C}$. The supernatant was removed and the RNA pellet was air-dried for $10 \mathrm{~min}$. RNA was dissolved in diethylpyrocarbonate (DEPC)-treated water by passing the solution a few times through a pipette tip.

Total RNA was treated with $1 \mathrm{U}$ of RQ1 RNasefree DNase (Invitrogen, Germany) to digest DNA residues, and re-suspended in DEPC-treated water. Purity of total RNA was assessed by the 260/ $280 \mathrm{~nm}$ ratio (between 1.8 and 2.1). Additionally, integrity was assured with ethidium bromide-stain analysis of $28 \mathrm{~S}$ and $18 \mathrm{~S}$ bands by formaldehydecontaining agarose gel electrophoresis. Aliquots were used immediately for reverse transcription (RT).

\section{Reverse transcription reaction}

The complete poly $(A)^{+}$RNA isolated from male rat tissues was reverse transcribed into CDNA in a total volume of $20 \mu \mathrm{l}$ using RevertAidTM First Strand cDNA Synthesis Kit (MBI Fermentas, Germany). An amount of total RNA ( $5 \mu \mathrm{g})$ was used with a reaction mixture, termed the master mix (MM). The MM consisted of $50 \mathrm{mM} \mathrm{MgCl}_{2}, 5 \times \mathrm{RT}$ buffer (50 mM KCl; 10 mM Tris- $\mathrm{HCl}$; pH 8.3; $10 \mathrm{mM}$ of each dNTP), $50 \mu \mathrm{M}$ oligo-dT primer, $20 \mathrm{U}$ ribonuclease inhibitor (50 kDa recombinant enzyme to inhibit RNase activity) and $50 \mathrm{U}$ M-MuLV reverse transcriptase. The RT reaction was carried out at $25^{\circ} \mathrm{C}$ for $10 \mathrm{~min}$, followed by $1 \mathrm{~h}$ at $42^{\circ} \mathrm{C}$, and the reaction was stopped by heating for $5 \mathrm{~min}$ at $99^{\circ} \mathrm{C}$. Afterwards the reaction tubes containing RT preparations were flash-cooled in an ice chamber until being used for DNA amplification through semiquantitative real time-polymerase chain reaction (sqRT-PCR).

\section{Semi-quantitative real time-polymerase chain reaction}

Polymerase chain reaction reactions were set up in $25 \mu \mathrm{l}$ reaction mixtures containing $12.5 \mu \mathrm{l}$ of 1× SYBR ${ }^{\circledR}$ Premix Ex TaqTM (TaKaRa, Biotech. Co. Ltd., Germany), $0.5 \mu \mathrm{l}$ of $0.2 \mu \mathrm{M}$ sense primers, $0.5 \mu \mathrm{l}$ of $0.2 \mu \mathrm{M}$ antisense primer, $6.5 \mu \mathrm{l}$ of distilled water, and $5 \mu \mathrm{l}$ of $\mathrm{cDNA}$ template. The reaction program was allocated to 3 steps. The first step was at $95.0^{\circ} \mathrm{C}$ for $3 \mathrm{~min}$. The second step consisted of 40 cycles in which each cycle was divided into 3 steps: (a) at $95.0^{\circ} \mathrm{C}$ for $15 \mathrm{~s}$; (b) at $55.0^{\circ} \mathrm{C}$ for $30 \mathrm{~s}$; and (c) at $72.0^{\circ} \mathrm{C}$ for $30 \mathrm{~s}$. The third step consisted of 71 cycles which started at $60.0^{\circ} \mathrm{C}$ and then increased about $0.5^{\circ} \mathrm{C}$ every $10 \mathrm{~s}$ up to $95.0^{\circ} \mathrm{C}$. At the end of each sqRT-PCR a melting curve analysis was performed at $95.0^{\circ} \mathrm{C}$ to check the quality of the used primers. Each experiment included a distilled water control.

The semi-quantitative values of RT-PCR (sqRTPCR) of aromatase (Cyp19-F: 5'-ATA CCA GGT CCT GGC TAC TG-3', Cyp19-R: 5'-TTG TTG TTA AAT ATG ATG CC-3' [27]), LH (LH -F: 5'-TCT CAC CACCAC CGT CTG TA-3', LH-R: 5'-TGC AGT CGC TGT AGT CCA TC-3' [27]), and FSH (FSH-F: 5'-GGG CCA GGA ACT GTG AAA TA-3', FSH-R: 5'-TCT CAG AAC TGC CGA GGT TT$3^{\prime}$ [27]) genes were normalized on the bases of $\beta$ actin ( $\beta$-actin-F: $5^{\prime}$-TTG CCG ACA GGA TGC AGA A3', $\beta$-actin-R: 5'-GCC GAT CCA CAC GGA GTA CT-3' [27]) expression.

\section{Calculation of gene expression}

First the amplification efficiency (Ef) was calculated from the slope of the standard curve using the following formulae [28]: $E f=10^{-1 / \text { slope }}$, efficiency $(\%)=(E f-1) \times 100$. The relative quantification of the target to the reference was determined by using the $\Delta C T$ method if $\mathrm{E}$ for the target (Cyp19, $\mathrm{LH}$ and $\mathrm{FSH}$ ) and the reference primers ( $\beta$-actin) are the same [28]:

ratio $_{(\text {reference/target gene) }}=\mathrm{Ef} \mathrm{CT}$ (reference) $-\mathrm{CT}$ (target) .

\section{Statistical analysis}

All data were analyzed using the General Linear Models (GLM) procedure of Statistical Analysis System [29] followed by the Scheffé test to assess significant differences between groups. The values are expressed as mean \pm SEM. All statements of significance were based on probability of $p<0.05$. 
Table I. Concentrations of testosterone, $\mathrm{LH}$, and FSH in melatonin- and/or ZNS-treated rats

\begin{tabular}{|c|c|c|c|}
\hline Groups & $\begin{array}{c}\text { Free } \\
\text { testosterone } \\
{[\mathrm{ng} / \mathrm{l}]}\end{array}$ & $\begin{array}{c}\mathrm{LH} \\
{[\mathrm{mlU} / \mathrm{ml}]}\end{array}$ & $\begin{array}{c}\text { FSH } \\
{[\mathrm{mlU} / \mathrm{ml}]}\end{array}$ \\
\hline Control & $5.82 \pm 0.32^{a}$ & $1.92 \pm 0.10^{a}$ & $1.43 \pm 0.07 a$ \\
\hline Melatonin & $7.48 \pm 0.24^{a}$ & $2.34 \pm 0.11^{a}$ & $1.72 \pm 0.03^{a}$ \\
\hline ZNS10 & $5.24 \pm 0.34^{a b}$ & $1.74 \pm 0.10^{a}$ & $1.13 \pm 0.11^{a}$ \\
\hline ZNS20 & $3.46 \pm 0.22^{b}$ & $1.23 \pm 0.07^{a b}$ & $0.78 \pm 0.06^{b}$ \\
\hline ZNS50 & $2.82 \pm 0.14^{b}$ & $0.74 \pm 0.10^{b}$ & $0.57 \pm 0.10^{b c}$ \\
\hline $\begin{array}{l}\text { Melatonin } \\
+ \text { ZNS10 }\end{array}$ & $5.95 \pm 0.52^{\mathrm{a}}$ & $1.89 \pm 0.12^{a}$ & $1.21 \pm 0.07^{a}$ \\
\hline $\begin{array}{l}\text { Melatonin } \\
+ \text { ZNS20 }\end{array}$ & $5.12 \pm 0.13^{a b}$ & $1.69 \pm 0.10^{a}$ & $1.10 \pm 0.04^{a}$ \\
\hline $\begin{array}{l}\text { Melatonin } \\
+ \text { ZNS50 }\end{array}$ & $4.96 \pm 0.16^{b}$ & $1.41 \pm 0.07 a b$ & $0.94 \pm 0.06^{b}$ \\
\hline$C P$ & $1.46 \pm 0.21^{c}$ & $0.51 \pm 0.06^{b}$ & $0.41 \pm 0.03 c$ \\
\hline
\end{tabular}

\section{Results}

\section{Hormonal assessment}

The results depicted in Table I show the effect of ZNS exposure and/or melatonin on serum levels of free testosterone, $\mathrm{LH}$, and FSH of adult male rats. The results indicated that there were significant decreases in serum free testosterone, $\mathrm{LH}$, and FSH in male rats treated with medium and high doses of ZNS compared with the control group (Table I). However, the levels of free testosterone, $\mathrm{LH}$, and FSH in rats treated with a low dose of ZNS were relatively similar to the control group. In contrast, treatment of male rats with melatonin increased

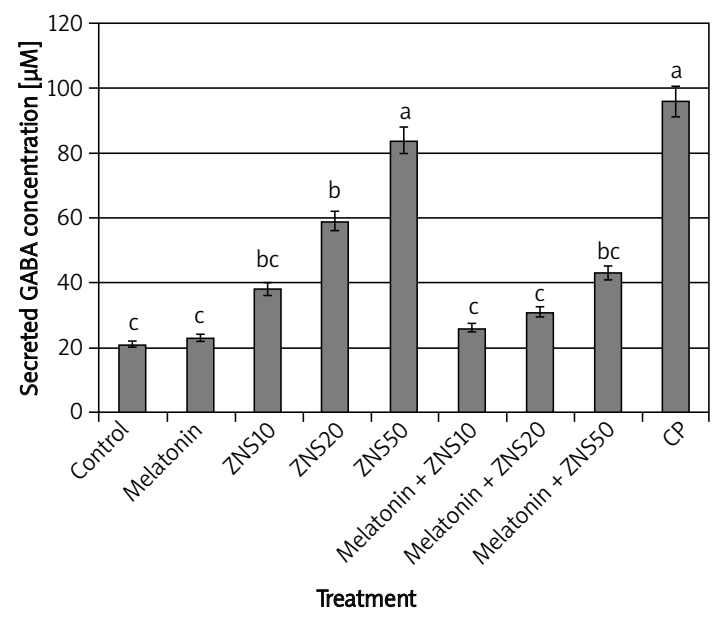

Figure 1. Comparison of GABA secretion in liver tissues of male rats after exposure to ZNS and/or melatonin. Mean values in the same column with different superscript letters differ significantly $(p<0.05)$ ZNS - Zonisamide, iNOS - inducible nitric oxide synthase, $C P$-cyclophosphamide. the levels of free testosterone, LH, and FSH compared with control rats. Moreover, treatment of male rats with melatonin significantly increased the secretion of free testosterone, $\mathrm{LH}$, and FSH in rats treated with low and medium doses of ZNS compared with the levels in rats treated with ZNS alone (Table I). In addition, the levels of free testosterone, $\mathrm{LH}$, and FSH were increased with melatonin plus high dose of ZNS compared with ZNS alone; however, the levels were not significantly different (Table I). On the other hand, the levels of free testosterone, LH, and FSH were significantly decreased in rats treated with CP compared with the control group (Table I).

\section{Secretion of $\gamma$-aminobutyric acid}

The secretion of GABA after treatment of male rats with ZNS and/or melatonin was determined in liver tissues (Figure 1). The results revealed that GABA concentration in melatonin treated rats was similar to that in the control group. However, treatment of male rats with medium and high doses of ZNS significantly increased the GABA level in liver tissues compared with the control group (Figure 1). In the same trend, the level of GABA increased in male rats treated with CP compared with the control group. In contrast, treatment of ZNS-treated rats with melatonin significantly decreased the concentration of GABA in all groups of rats treated with ZNS plus melatonin compared with those treated with ZNS alone (Figure 1).

\section{Determination of inducible nitric oxide synthase activity}

Compared with the control group, iNOS activity was significantly high in testis tissues of male rats treated with all doses of ZNS or with CP (Figure 2). However, treatment of male rats with melatonin did not increase the iNOS activity compared with the control group. Moreover, treatment of ZNS-treated rats with melatonin significantly decreased the activity of iNOS in all groups of rats treated with ZNS plus melatonin compared with those treated with ZNS alone (Figure 2).

\section{Assessment of sperm abnormalities}

The mean values of different types of abnormalities of sperm morphology are shown in Table II. The most frequently observed abnormality was head without hock and coiled tail sperm.

The results revealed that melatonin treatment did not increase the frequencies of the morphologically abnormal sperm compared with the control group (Table II). In addition, there was no difference in the frequencies of the morphologically 
abnormal sperm at the low dose treatment of ZNS compared with the control group. However, the frequency of sperm abnormalities increased significantly with the medium and high doses of ZNS compared with the control group (Table II).

On the other hand, treatment of male rats with melatonin decreased the frequency of sperm abnormalities in ZNS-treated rats. However, the frequency of sperm abnormalities increased significantly with CP treatment compared with control and other treatment groups (Table II).

\section{DNA fragmentation}

Quantitative DNA fragmentation was determined in rats exposed to ZNS alone or in combination with melatonin. The DNA damage was examined in testis tissues collected from ZNS-treated groups using gel electrophoresis laddering assay (Figure 3). The results of this assay revealed that ZNS treatment increased the DNA damage compared with the control group (Figure 3). DNA damage was observed with medium and high doses of ZNS. However, the low dose of ZNS did not induce damage in the DNA of the testis tissues of male rats.

On the other hand, the DNA remained without damage when the male rats were treated with melatonin. Furthermore, treatment of ZNS-treated rats with melatonin decreased the DNA damage compared with rats treated with ZNS alone. In contrast, the enhancement of the DNA damage with CP treatment was more effective than ZNS treatment (Figure 3).

\section{Expression analysis of CYP19, $\mathrm{LH}$ and FSH genes}

The effect of melatonin and ZNS on the expression of CYP19 in the testis tissues and LH as well

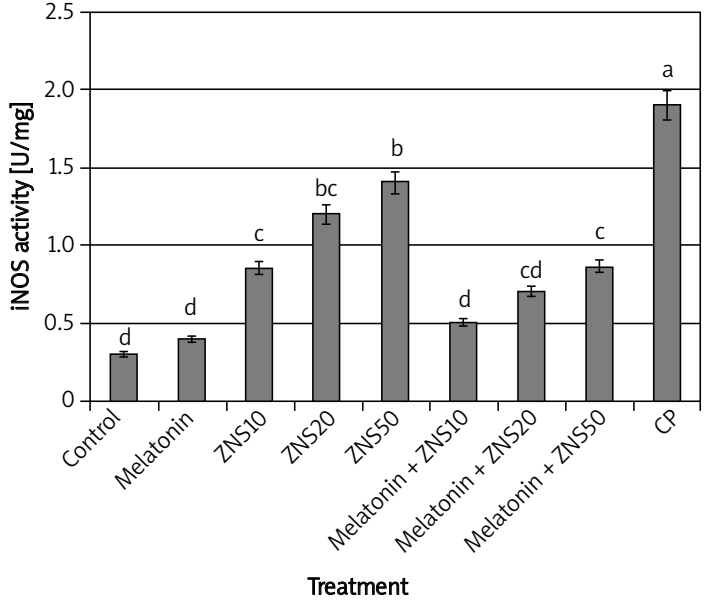

Figure 2. Comparison of iNOS activity in testis tissues of male rats after exposure to ZNS and/or melatonin. Mean values in the same column with different superscript letters differ significantly $(p<0.05)$ ZNS - Zonisamide, iNOS - inducible nitric oxide synthase, $C P$-cyclophosphamide.

as FSH genes in pituitary tissues of adult male rats is summarized in Figures 4-6.

The expression levels of CYP19, LH and FSH genes were increased with melatonin compared with the control group; however, the increase of the expression levels was significant in CYP19 and FSH genes (Figures 4-6).

On the other hand, treatment of male rats with low and medium doses of ZNS slightly decreased the levels of CYP19, LH and FSH genes compared with the control group. However, the levels of CYP19, LH and FSH genes decreased significantly with high dose of ZNS compared with the control group (Figures 4-6).

Supplementation of ZNS-treated rats with melatonin increased the expression levels of CYP19, LH and FSH genes. The expression levels in ZNS-treated rats exposed to melatonin were relatively simi-

Table II. Mean values of different types of sperm abnormalities induced by melatonin and/or ZNS in male rats

\begin{tabular}{|c|c|c|c|c|c|}
\hline \multirow[t]{2}{*}{ Treatment } & \multicolumn{5}{|c|}{ Sperm abnormalities* } \\
\hline & Head without hock & Amorphous head & Banana head & Coiled tail & Total \\
\hline Control & $0.4 \pm 0.1^{c}$ & $0.0 \pm 0.0$ & $0.2 \pm 0.0^{b}$ & $0.2 \pm 0.1^{c}$ & $0.8 \pm 0.1^{d}$ \\
\hline Melatonin & $0.4 \pm 0.0^{c}$ & $0.0 \pm 0.0$ & $0.2 \pm 0.1^{b}$ & $0.3 \pm 0.1^{c}$ & $0.9 \pm 0.1^{d}$ \\
\hline ZNS10 & $0.6 \pm 0.1^{c}$ & $0.3 \pm 0.0^{c}$ & $0.4 \pm 0.1^{b}$ & $0.5 \pm 0.1^{c}$ & $1.8 \pm 0.2^{c}$ \\
\hline ZNS20 & $0.8 \pm 0.0^{b}$ & $0.6 \pm 0.1^{b}$ & $0.5 \pm 0.1^{a b}$ & $0.5 \pm 0.1^{b c}$ & $2.4 \pm 0.1^{c}$ \\
\hline ZNS50 & $1.2 \pm 0.2^{a b}$ & $0.7 \pm 0.1^{b}$ & $0.6 \pm 0.1^{a b}$ & $0.7 \pm 0.1^{b}$ & $3.2 \pm 0.2^{b}$ \\
\hline Melatonin + ZNS10 & $0.5 \pm 0.1^{b c}$ & $0.2 \pm 0.0^{c}$ & $0.3 \pm 0.1^{b}$ & $0.3 \pm 0.1^{c}$ & $1.3 \pm 0.2^{\mathrm{cd}}$ \\
\hline Melatonin + ZNS20 & $0.7 \pm 0.0^{b}$ & $0.4 \pm 0.1^{b c}$ & $0.3 \pm 0.1^{b}$ & $0.3 \pm 0.1^{c}$ & $1.7 \pm 0.1^{c}$ \\
\hline Melatonin + ZNS50 & $0.8 \pm 0.2^{b}$ & $0.5 \pm 0.1^{b c}$ & $0.5 \pm 0.1^{a b}$ & $0.4 \pm 0.1^{c}$ & $2.2 \pm 0.1^{c}$ \\
\hline$C P$ & $1.7 \pm 0.2^{\mathrm{a}}$ & $1.2 \pm 0.1^{\mathrm{a}}$ & $0.9 \pm 0.1^{a}$ & $1.4 \pm 0.2^{\mathrm{a}}$ & $5.2 \pm 0.3^{a}$ \\
\hline
\end{tabular}

${ }^{*}$ After 35 days of treatment the other 5 animals of each group were used to assess the sperm morphology. $a, b, c, d$ Mean values within columns with unlike superscript letters were significantly different ( $p<0.05$, Scheffé test). $b, b c, c, d, d c$ Mean values within columns with similar superscript letters were not significantly different $(p>0.05)$. 


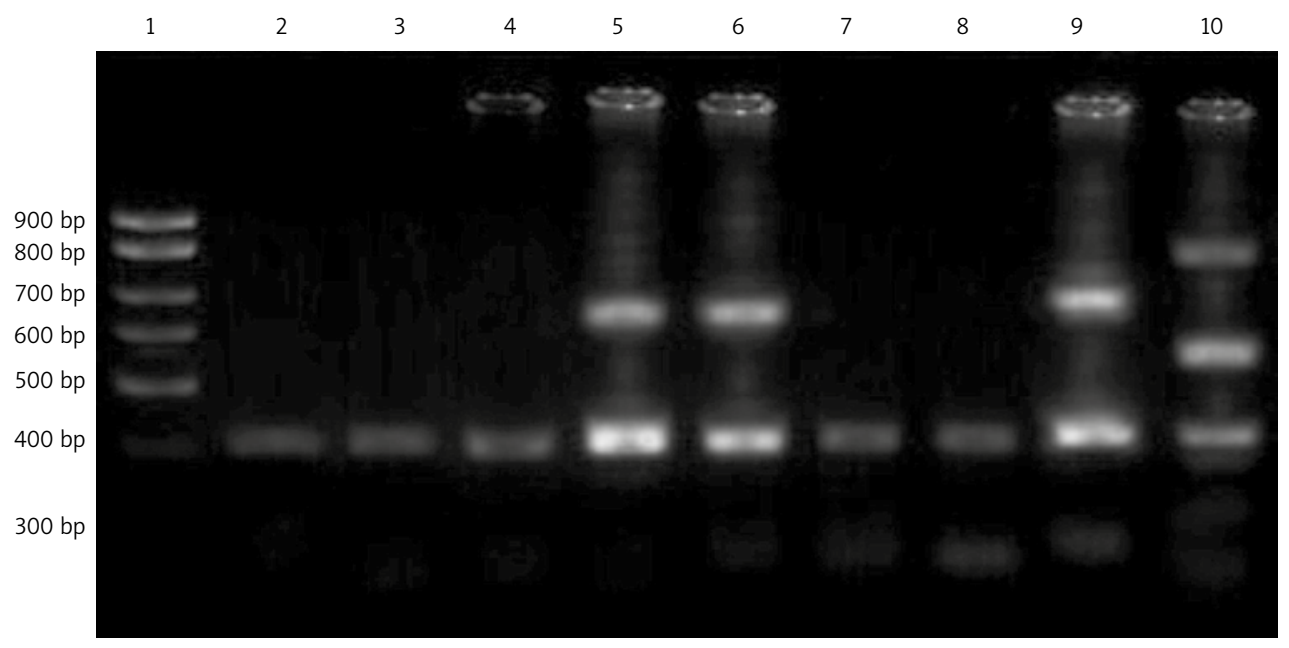

Figure 3. DNA fragmentation detected with agarose gel of DNA extracted from testis tissues of rats exposed to ZNS and/or melatonin analyzed by DNA gel electrophoresis laddering assay. Lane 1 represents DNA ladder. Lane 2 represents control samples. Lane 3 shows DNA fragmentation in testis tissues following melatonin exposure. Lanes 46 show DNA fragmentation in testis tissues following 10, 20 and $50 \mathrm{mg} / \mathrm{kg}$ of ZNS, respectively. Lanes 7-9 show DNA fragmentation in testis tissues following melatonin plus ZNS as in lanes 4-6. Lane 10 represents CP-treated samples

lar to the control group (Figures 4-6). In contrast, the expression levels of CYP19, LH and FSH genes were decreased significantly with CP treatment (Figures 4-6).

\section{Discussion}

The results of the present study revealed that ZNS decreased the levels of serum free testosterone, $\mathrm{LH}$, and FSH in male rats, especially with the medium and high dose. In addition, the frequency of sperm abnormalities increased significantly with the medium and high doses of ZNS compared with the control group. To our knowledge, there are no published data regarding the effect of ZNS on the

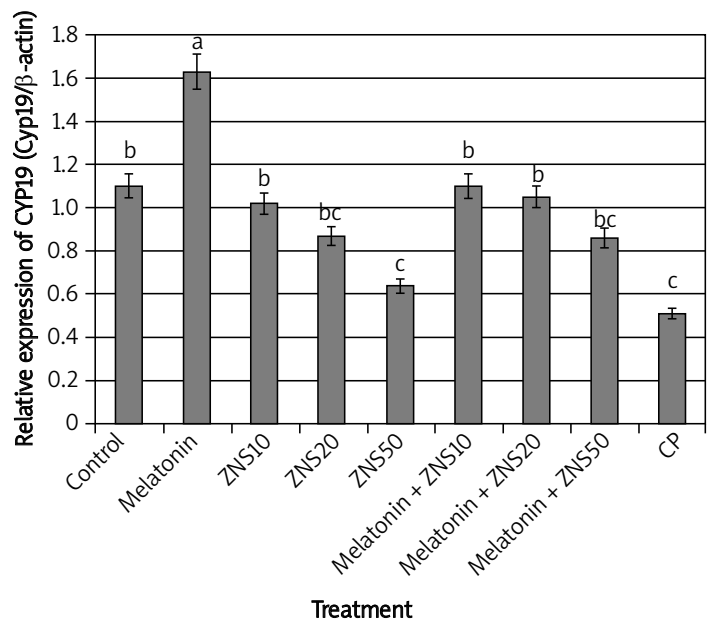

Figure 4. Relative expression of CYP19 gene in testis of male rats after exposure to ZNS and/or melatonin. Mean values in the same column with different superscript letters differ significantly $(p<0.05)$ ZNS - Zonisamide, CP - cyclophosphamide. fertility hormone and sperm abnormalities in male rats. So, the mechanism of action of ZNS on the fertility symptoms remained not understood. However, the effects of ZNS on neurotransmission and intracellular calcium have been evaluated in several preclinical studies. Results from these studies suggest that ZNS reduces calcium-dependent, potassium-evoked extracellular glutamate release in the hippocampus [30, 31]. Consistently with this, the current results revealed that ZNS increased the extracellular GABA concentration in ZNS-treated rats compared with control rats. Since glutamate is an excitatory neurotransmitter, and excessive release of glutamate may produce seizures, a reduc-

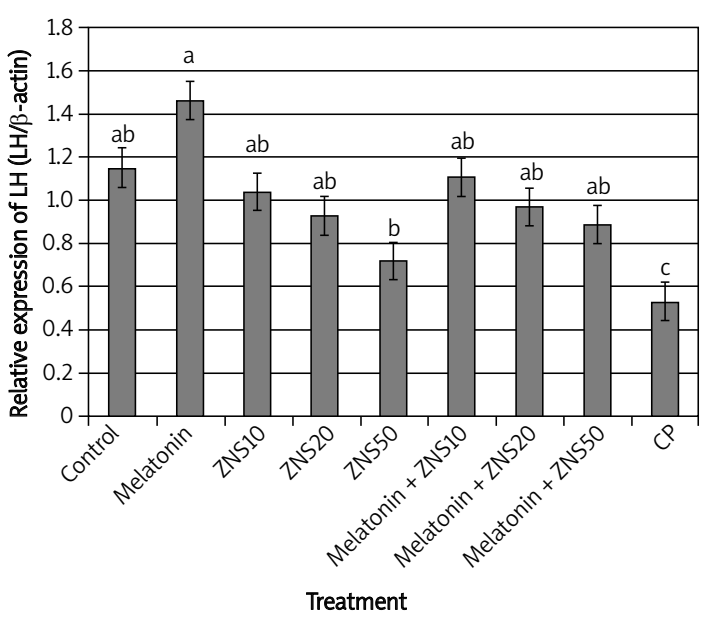

Figure 5. Relative expression of $\mathrm{LH}$ gene in brain tissues of male rats after exposure to ZNS and/or melatonin. Mean values in the same column with different superscript letters differ significantly $(p<0.05)$ ZNS - Zonisamide, CP-cyclophosphamide. 
tion in glutamate release may reduce seizure activity and may affect epileptogenesis [32]. Therefore, due to the negative effect of ZNS on free testosterone, $\mathrm{LH}$, and FSH levels and sperm viability it seems likely that ZNS has a negative feedback effect on the hypothalamus which affected the secretion of testosterone, $\mathrm{LH}$, and FSH-releasing hormone. In agreement with our suggestion, Ajayi and Akhigbe [33] reported that suppression of free testosterone and FSH is responsible for the decrease in sperm viability, motility, and morphology in male rats.

The results of the present study indicated that ZNS treatment increased the DNA damage compared with the control group. A little information regarding the effect of ZNS on DNA fragmentation was published. In disagreement with our study, Komatsu et al. [34] reported that ZNS, in concentrations of 50 and $100 \mathrm{mg} / \mathrm{kg}$ body weight, prevented the increase of $8-\mathrm{OHdG}$ levels, as a marker for DNA damage, within the cerebrum 30 min after iron solution injection. However, the difference in the Komatsu et al. [34] and our results is that they used only single doses of $50 \mathrm{mg} / \mathrm{kg}$ body weight and $100 \mathrm{mg} / \mathrm{kg}$ body weight of ZNS but we used a daily intake of ZNS for 4 weeks. So the main cause of ZNS-induced DNA damage in testis tissues of male rats in our results was the high concentrations of ZNS compared with the low concentrations of Komatsu et al. [34].

The current results demonstrated that the levels of CYP19, LH and FSH gene expression decreased significantly with the high dose of ZNS compared with the control group. The inhibitory effect of ZNS on gene expression may be attributed to its negative feedback effect on the hypothalamus and/or its effect on the DNA damage. The integrity of genomic information is critical to the survival and propagation of all cellular organisms. DNA damage that compromises genomic stability can result from environmental stresses and from cellular processes that occur during normal growth. Gasch et al. [35] reported that the multiple facets of the DNA damage response include cell-cycle arrest, alterations in gene expression, DNA damage repair, and cell death. Therefore, damage of the DNA influences the expression of many genes in the organism.

The present study indicated that melatonin increased the levels of serum free testosterone, $\mathrm{LH}$, and FSH, as well as expression of their encoding genes in male rats. Furthermore, melatonin improved the negative effect of ZNS on the secretion of free testosterone, $\mathrm{LH}$, and FSH, as well as expression of their encoding genes. In agreement with our findings, Díaz et al. [36] found that exogenous melatonin injection stimulated the secretion of $\mathrm{LH}$ and FSH pituitary responsiveness to luiteinz-

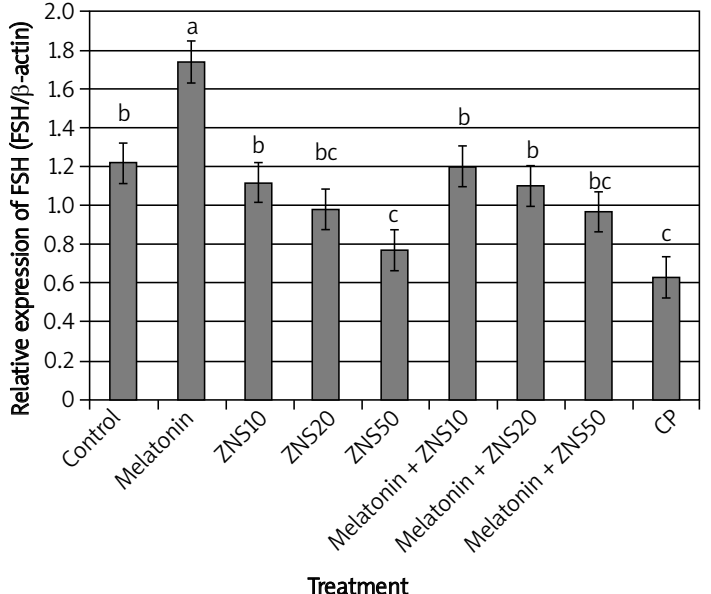

Figure 6. Relative expression of FSH gene in brain tissues of male rats after exposure to ZNS and/or melatonin. Mean values in the same column with different superscript letters differ significantly $(p<0.05)$ ZNS - Zonisamide, CP-cyclophosphamide.

ing hormone-releasing hormone (LHRH). In addition, Cagnacci et al. [37] reported a stimulatory effect of melatonin on the gonadotrophin response to physiological or submaximal doses of LHRH during the follicular phase of the menstrual cycle in women. Moreover, according to Li et al. [38] melatonin treatment resulted in $11 \%$ increase in the expression of the $\mathrm{GnRH}$ gene in young male rats. They suggested that the decrease in $\mathrm{GnRH}$ gene expression which is likely involved in the decline of reproductive functions in aging can be totally reversed by short-term administration of melatonin. However, understanding how melatonin augments this pituitary response to $\mathrm{GnRH}$ remains unknown. The presence of specific melatonin receptors in the pars tuberalis in rodents [39] and humans [40] supports a direct effect of melatonin on pituitary cells. However, the effect of melatonin on the hypothalamic nuclei mentioned above, which directly or indirectly influences the pituitary response to $\mathrm{GnRH}$, cannot be disregarded.

The effect of melatonin on sperm morphology indicated in the present study that melatonin decreased the oxidative impact of ZNS-induced sperm abnormalities. Consistently, Koksal et al. [41] found that melatonin is a potent antioxidant agent in preventing testicular post-ischemic reperfusion injury, as shown by the increased Johnsen's score and changed abnormal sperm rate in male rats. In addition, Kurcer et al. [42] reported that melatonin treatment significantly decreased the sperm abnormalities when compared with the ischemia/reperfusion injured samples in male rats.

Our current study showed that melatonin decreased the DNA fragmentation in testis tissues induced by ZNS. This correlates with the study of Vargas et al. [43], who found that the quality of 
sperm DNA, fragmentation, unpacking and DNA stability diminished in male mice exposed to hypoxia and treated with melatonin. The mechanism of melatonin in preventing DNA damage was suggested by Espino et al. [44], who posited that the preventive role of melatonin against damage induced by the mutagens possibly takes place via melatonin receptor- and extracellular signal-regulated kinase-mediated pathways. In addition, they found that the damage in the DNA of the sperm was attributed to increased lipid peroxidation in sperm cells. However, pre-treatment with melatonin 30 min before the administration of diazinon was able to completely prevent the increase of lipid peroxidation in epididymal sperm cells from mice treated with diazinon. In the present study, melatonin decreased the sperm abnormalities, which can probably be attributed to decreased lipid peroxidation in the sperm cells. Moreover, the current study found that melatonin decreased the oxidation stress in the form of iNOS in testis tissues of male rats treated with ZNS plus melatonin compared with those treated with ZNS alone.

In conclusion, the administration of melatonin prior to exposure to ZNS prevents the alteration of reproductive parameters including serum free testosterone, $\mathrm{LH}$, and FSH and expression of their encoding genes, sperm morphology and DNA fragmentation in male rats, possibly due to its antioxidant properties. Melatonin could be used to reduce the toxic damage of ZNS and it is recommended to be taken prior to ZNS supplementation against PD.

\section{Acknowledgments}

The biochemical assays were done in King Fahad Medical Research Center, Jeddah, Saudi Arabia. However, the other analyses were carried out in the National Research Centre, Egypt. The authors thank everyone who assisted in this study.

\section{Conflict of interest}

The authors declare no conflict of interest.

\section{References}

1. Faught E, Ayala R, Montouris GG, et al. Randomized controlled trial of zonisamide for the treatment of refractory partial-onset seizures. Neurology 2001; 57: 1774-9.

2. Sackellares JC, Ramsay RE, Wilder BJ, et al. Randomized, controlled clinical trial of zonisamide as adjunctive treatment for refractory partial seizures. Epilepsia 2004; 45: 610-7.

3. Seino M. Review of zonisamide development in Japan. Seizure 2004; 13 (Suppl. 1): S2-4.

4. Bermejo PE, Dorado R. Zonisamide for migraine prophylaxis in patients refractory to topiramate. Clin Neuropharmacol 2009; 32: 103-6.

5. Atli A, Theodore BR, Turk DC, Loeser JD. Zonisamide in the treatment of painful diabetic neuropathy: a randomized, double-blind, placebo-controlled pilot study. Pain Med 2010; 11: 1010-6.

6. Bermejo PE, Ruiz-Huete C, Dorado R, Anciones B. Zonisamide in refractory essential tremor. Rev Neurol 2008; 46: 139-42.

7. Kinrys G, Vasconcelose Sa D, Nery F. Adjunctive zonisamide for treatment refractory anxiety. Int I Clin Pract 2007; 61: 1050-3.

8. Murata M, Hasegawa K, Kanazawa I; Japan Zonisamide on PD Study Group. Zonisamide improves motor function in Parkinson disease: a randomized, double-blind study. Neurology 2007; 68: 45-50.

9. Bermejo PE, Ruiz-Huete C, Anciones B. Zonisamide in managing impulse control disorders in Parkinson's disease. J Neurol 2010; 257: 1682-5.

10. Reiter RJ. Pineal melatonin: cell biology of its synthesis and of its physiological interactions. Endocr Rev 1991; 12: 151-80.

11. Carrillo-Vico A, Reiter RJ, Lardone PJ, et al. The modulatory role of melatonin on immune responsiveness. Curr Opinion Investig Drugs 2006; 7: 423-31.

12. Dullo P, Chaudhary R. Short review of reproductive physiology of melatonin. Pak J Physiol 2009; 5: 46-8.

13. Voordouw BC, Euser R, Verdonk RE, et al. Melatonin and melatoninprogestin combination after pituitary-ovulation function in women and can inhibit ovulation. J Clin Endocrinol Metab 1992; 74: 108-17.

14. Wojtowicz M, Jakill G. Melatonin and its role in human reproduction. Ginekol Pol 2002; 73: 1231-7.

15. Mayo JC, Sainz RM, Tan DX, et al. Anti-inflammatory actions of melatonin and its metabolites, N1-acetyl-N2formyl-5-methoxykynuramine (AFMK) and N1-acetyl-5methoxykynuramine (AMK), in macrophages. J Neuroimmunol 2005; 165: 139-49.

16. Hardeland R, Cardinali DP, Srinivasan V, et al. Melatonin - a pleiotropic, orchestrating regulator molecule. Prog Neurobiol 2011; 93: 350-84.

17. Yassa VF, Girgis SM, Abumourad MK. Potential protective effects of vitamin $E$ on diazinon-induced DNA damage and some haematological and biochemical alterations in rats. J Medit Ecol 2011; 11: 31-9.

18. Ahmed EA, Omar HM, Elghaffar SK, et al. The antioxidant activity of vitamin C, DPPD and L-cysteine against Cisplatin-induced testicular oxidative damage in rats. Food Chem Toxicol 2011; 49: 1115-21.

19. Elmegeed GA, Khali WKB, Abdel Raouf A, Abdelhalim MM Synthesis and in vivo anti-mutagenic activity of novel melatonin derivatives. Eur J Med Chem 2008; 43: 763-70.

20. Wilfong AA, Willmore LJ. Zonisamide - a review of experience and use in partial seizures. Neuropsychiatr Dis Treat 2006; 2: 269-80.

21. McCann D, Kirkish L. Evaluation of free testosterone in serum. J Clin Immunoassay 1985; 8: 234-6.

22. Knobil $E$. The neuroendocrine control of the menstrual cycle. Rec Prog Horm Res 1980; 36: 52-88.

23. Wakabayashi K. Heterogeneity of rat luteinizing hormone revealed by radioimmunoassy and electrofocusing studies. Endocrinol Jap 1977; 24: 473-85.

24. Hana HY, Khalil WKB, Elmakawy Al, Elmeeged GA. Androgenic profile and genotoxicity evaluation of testosterone propionate and novel synthesized heterocyclic steroids. J Steroid Biochem Mol Biology 2008; 110: 284-94.

25. Jeong SH, Kim BY, Kang HG, et al. Effects of butylated hydroxyanisole on the development and functions of reproductive system in rats. Toxicology 2005; 208: 49-62.

26. Lu T, Xu Y, Mericle MT, Mellgren RL. Participation of the conventional calpains in apoptosis. Biochim Biophys Acta 2002; 1590: 16-26. 
27. El-Habashi AA, Mousa MA, El-Eraky WI, Khalil WKB, Ahmed HH, Moad NAA. Possible mechanisms for the toxic effects of marijuana smoke on the reproductive axis of male albino rats. J Appl Pharmaceut Sci 2013; 3: S59-67.

28. Bio-Rad Laboratories Inc. Real-Time PCR Applications Guide. Bulletin 2006; 5279: 101.

29. SAS. SAS user's guide: statistics, edn. SAS Institute Inc. Cary, NC. 1982.

30. Okada M, Kawata Y, Mizuno K, et al. Interaction between $\mathrm{Ca}+, \mathrm{K}+$, carbamazepine and zonisamide on hippocampal extracellular glutamate monitored with a microdialysis electrode. Br J Pharmacol 1998; 124: 1277-85.

31. Zhu W, Rogawski MA. Zonisamide depresses excitatory synaptic transmission by a presynaptic action [abstract]. Annual Meeting of the American Epilepsy Society. Orlando, FL. 1999 Dec 3-8. Epilepsia 1999; 40 (Suppl. 7): 245.

32. Carlson H, Ronne-Engstrom E, Ungerstedt U, et al. Seizure related elevations of extracellular amino acids in human focal epilepsy. Neurosci Lett 1992; 140: 30-2.

33. Ajayi AF, Akhigbe RE. Antifertility activity of Cryptolepis sanguinolenta leaf ethanolic extract in male rats. J Hum Reprod Sci 2012; 5: 43-7.

34. Komatsu M, Hiramatsu M, Willmore LJ. Zonisamide reduces the increase in 8 -hydroxy-2'-deoxyguanosine levels formed during iron-induced epileptogenesis in the brains of rats. Epilepsia 2000; 41: 1091-94.

35. Gasch AP, Huang M, Metzner S, Botstein D, Elledge SJ, Brown PO. Genomic expression responses to DNAdamaging agents and the regulatory role of the yeast ATR homolog Mec1p. Mol Biol Cell 2001; 12: 2987-3003.

36. Díaz E, Fernández C, Castrillón PO, Esquifino Al, Marín B, Díaz López B. Effect of exogenous melatonin on neuroendocrine-reproductive function of middle-aged female rats. J Reprod Fertil 1999; 117: 331-7.

37. Cagnacci A, Paoletti AM, Soldani R, Orru M, Maschio E, Melis GB. Melatonin enhances the luteinizing hormone and follicle-stimulating hormone responses to gonadotrophin-releasing hormone in the follicular, but not in the luteal, menstrual phase. J Clin Endocr Metabol 1995; 80: 1095-9.

38. Li S, Givalois L, Pelletier G. Effects of aging and melatonin administration on gonadotropin-releasing hormones $(\mathrm{GnRH})$ gene expression in the male and female rat. Peptides 1997; 18: 1023-8.

39. Weaver DR, Reppert SM. Melatonin receptors are present in the ferret pars tuberalis and pars distalis, but not in brain. Endocrinology 1989; 45: 955-65.

40. Weaver DR, Stehle JH, Stopa EG, Reppert SM. Melatonin receptors in human hypothalamus and pituitary: implications for circadian and reproduction responses to melatonin. J Clin Endocrinol Metabol 1993; 76: 295-301.

41. Koksal M, Oğuz E, Baba F, et al. Effects of melatonin on testis histology, oxidative stress and spermatogenesis after experimental testis ischemia-reperfusion in rats. Eur Rev Med Pharmacol Sci 2012; 16: 582-8.

42. Kurcer Z, Hekimoglu A, Aral F, Baba F, Sahna E. Effect of melatonin on epididymal sperm quality after testicular ischemia/reperfusion in rats. Fertil Steril 2010; 93: 1545-9.

43. Vargas A, Bustos-Obregón E, Hartley R. Effects of hypoxia on epididymal sperm parameters and protective role of ibuprofen and melatonin. Biol Res 2011; 44: 161-7.

44. Espino J, Ortiz Á, Bejarano I, et al. Melatonin protects human spermatozoa from apoptosis via melatonin receptor- and extracellular signal-regulated kinasemediated pathways. Fertil. Steril 2011; 95: 2290-6. 